\title{
Intracranial hemorrhage with fatal outcome in a patient with heparin induced bullous hemorrhagic dermatosis
}

\author{
Heparin ile tetiklenen hemorajik büllöz dermatoz hastasında fatal seyreden \\ intrakraniyal hemoraji
}

\section{Summary}

Bullous hemorrhagic dermatosis is a rare adverse effect of subcutaneous heparin injection. Here, we report a case of hemorrhagic bullous dermatosis occurred after enoxaparin use. The patient's lesions had resolved but she died 45 days after development of hemorrhagic bullous dermatosis due to intracranial hemorrhage.

Keywords: Hemorrhagic bullae, enoxaparin, heparin

\section{Öz}

Büllöz hemorajik dermatoz, heparin kullanımına bağlı nadir görülen bir yan etkidir. Biz burada enoksaparin kullanımı sonrası hemorajik bülleri gelişen bir olgu sunuyoruz. Lezyonları ilerleyen günlerde gerilemesine rağmen hasta bül oluşumunu takiben 45. günde intrakraniyal hemoraji nedeniyle kaybedilmiştir.

Anahtar Kelimeler: Hemorajik bül, enoksaparin, heparin

\section{Introduction}

Bullous hemorrhagic dermatosis is a rare adverse effect of subcutaneous heparin injection. Here, we report a case of hemorrhagic bullous dermatosis occurring after enoxaparin use. Her lesions had resolved but she died in the following 45 days due to intracranial hemorrhage.

\section{Case Report}

The patient was a 77-year-old woman with rectal carcinoma and was started on enoxaparin treatment $60 \mathrm{mg}$ every 12 hours due to pulmonary embolism. She developed multiple, sharply demarcated hemorrhagic blisters on her ankles, medial aspect of the shins and dorsal aspects of the hands on the fifth day of treatment (Figure 1). In addition to this treatment, she was using lansoprazole intermittently for more than one year. There were no lesions detected on the enoxaparin injection sites. In addition to routine biochemistry and coagulation tests, platelet counts were within the normal range both at the time of treatment initiation and onset of lesions. Biopsy of the lesions revealed an intraepidermal blister filled with red blood cells without any vasculitic, thrombotic, or inflammatory changes in the dermis (Figure 2). On the basis of the previously reported cases, enoxaparin treatment was continued and lesions resolved in the following two weeks as expected. Unfortunately, the patient displayed new onset dysarthria by the fourth week of heparin treatment. Routine biochemistry investigations and coagulation tests were all within the normal limits excluding platelet count $\left(110.000 / \mathrm{mm}^{3}\right)$. Intracranial hemorrhage was visualized by computed tomography. Despite surgical intervention, the patient died on the seventh postoperative day.

\section{Discussion}

Enoxaparin and other heparin products are being widely used for prophylaxis and treatment of thromboembolic

Address for Correspondence/Yazışma Adresi: Aslan Yürekli MD, Gülhane Military Medical Academy, Department of Dermatology, Ankara, Turkey Phone: +90 5434146646 E-mail: aslanyurekli03@hotmail.com Received/Geliş Tarihi: 18.12.2015 Accepted/Kabul Tarihi: 24.12 .2015 
diseases. Heparin-induced skin lesions located on the injection sites are one of the most frequent unwanted adverse effects ${ }^{1}$. Apart from the injection site reactions, bullous hemorrhagic dermatosis associated with heparin products occurring distant from the injection site has rarely been reported ${ }^{2}$. Our case was consistent with the previously reported 20 cases $^{3}$ in consideration of time of onset, clinical and histopathological appearance and resolution of the lesions. Especially, resolution of lesions despite continuing heparin treatment gives an impression of benign course, however, the mechanism of action remains unknown. We believe that one of the most critical concerns of this condition is the probability of development of similar hemorrhagic lesions in internal organs. Intracranial hemorrhage developed in our patient is not identical to heparin-induced thrombocytopenia after four weeks of treatment and with a platelet count of $110.000 / \mathrm{mm}^{3}$ (previous value was $264.000 / \mathrm{mm}^{3}$ ). Although the platelet count of 110.000 is not low, it is enough to be directly related to intracranial

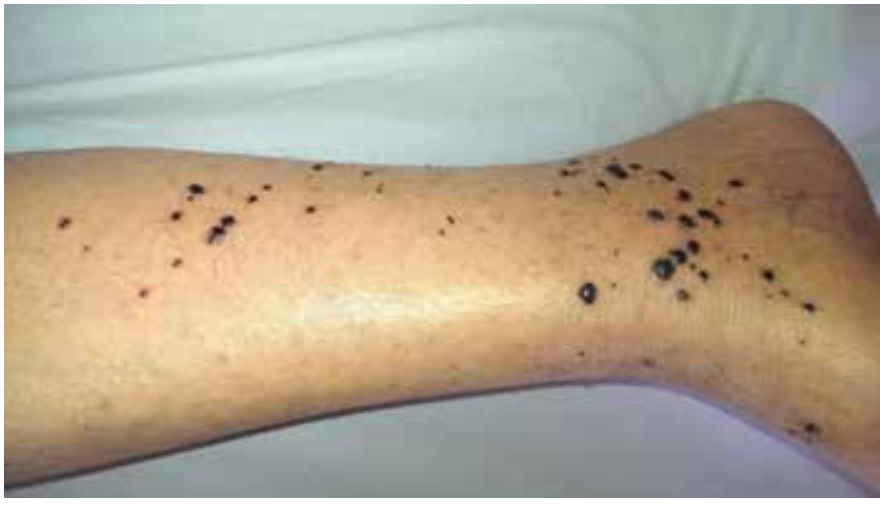

Figure 1. Multiple, black, sharply demarcated hemorrhagic blisters measuring $0.5-1 \mathrm{~cm}$ in diameter located on her ankles

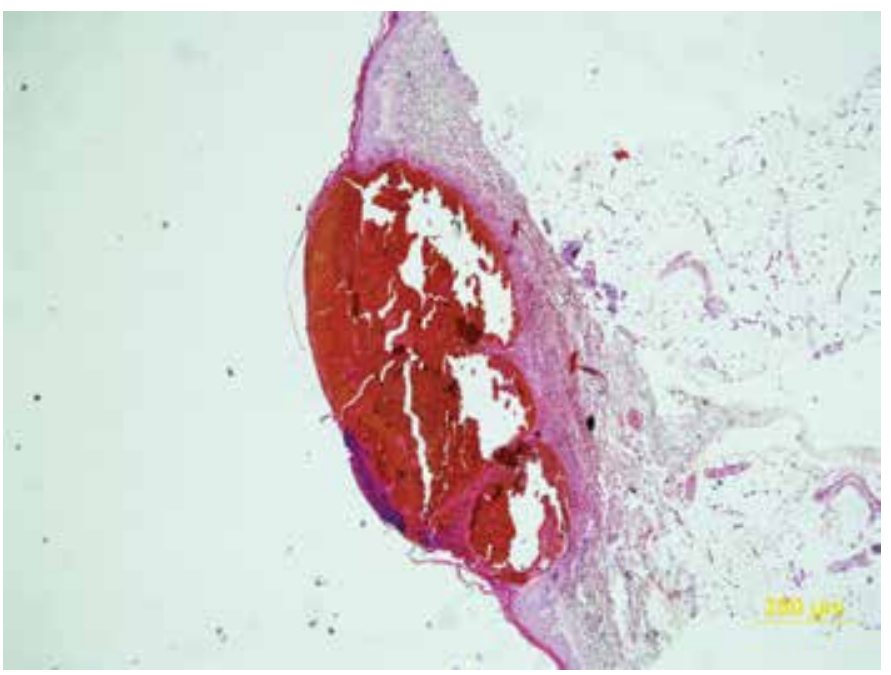

Figure 2. Histology of the lesions revealed intraepidermal blister filled with red blood cells (hematoxylineosin stain $\times 20$ ) hemorrhage; more than $50 \%$ decrease within platelet count is important for a causal relationship. In addition to our observation, we intended to state the clinical characteristics of previously reported cases related to mortality and we could attain 4 cases up to date2,4. Causes of death in these cases were stated to be sepsis for one patient, intracranial hemorrhage for two patients and were not defined in one case. Interestingly, thrombolytic treatments were continued for these cases. However, some authors expressed their doubts, suggesting cutaneous hemorrhagic bullae as a warning sign of potentially lethal complications 5 .

\section{Conclusion}

In conclusion, bullous hemorrhagic dermatosis associated with heparin use should be monitored closely, despite spontaneous regression and coagulation tests within the normal range. Emergence of lesions distant from heparin injection sites may point out a systemic effect which may not be restricted to skin. In patients whose platelet count decreases by more than $50 \%$, heparin treatment should be stopped and to initiate a therapy with a non-heparin anticoagulant such as a direct thrombin inhibitor should be considered.

\section{Ethics}

Informed Consent: Consent form was filled out by all participants. Peer-review: Internal peer-reviewed.

\section{Authorship Contributions}

Surgical and Medical Practices: Aslan Yürekli, Ercan Çalışkan, Concept: Aslan Yürekli, Ercan Çalışkan, Deniz Doğan, Design: Aslan Yürekli, Ercan Çalışkan, Data Collection or Processing: Aslan Yürekli, Analysis or Interpretation: Aslan Yürekli, Ercan Çalıskan, Literature Search: Deniz Doğan, Writing: Aslan Yürekli.

Conflict of Interest: No conflict of interest was declared by the authors. Financial Disclosure: The authors declared that this study has received no financial support.

\section{References}

1. Schindewolf M, Lindhoff-Last E, Ludwig RJ, Boehncke WH: Heparin-induced skin lesions. Lancet 2012;24;380:1867-79.

2. Perrinaud A, Jacobi D, Machet MC, ET AL: Bullous hemorrhagic dermatosis occurring at sites distant from subcutaneous injections of heparin: Three cases. J Am Acad Dermatol 2006;54(Suppl 2):5-7.

3. Öztürk S, Can I, Erden I, Akyol H, Solmaz OA. Enoxaparin-induced hemorrhagic bullous dermatosis in a leprosy patient. Cutan Ocul Toxicol 2015:34:254-6.

4. Maldonado Cid P, Moreno Alonso de Celada R, Herranz Pinto P, et al: Bullous hemorrhagic dermatosis at sites distant from subcutaneous injections of heparin: A report of 5 cases. J Am Acad Dermatol 2012;67:220-2.

5. Choudhry S, Fishman PM, Hernandez C. Heparin-induced bullous hemorrhagic dermatosis. Cutis 2013;91:93-8. 